\title{
Variation in Clone Fertility and its Effect on the Gene Diversity of Seeds From a Seed Orchard of Chamaecyparis obtusa in Korea
}

\author{
By K. S. KANG ${ }^{1, *)}$ and T. J. MulLIN ${ }^{2)}$
}

(Received 26 $6^{\text {th }}$ March 2006)

\begin{abstract}
Male and female strobilus production was assessed annually over a four-year period for a clonal seed orchard of hinoki (Chamaecyparis obtusa Endl.) in Korea. Clonal fertility and fertility variation, expressed by both sibling coefficient and coefficient of variation in strobilus production among 50 orchard clones, were reported. Fertility varied among clones and among years producing four-year averages per ramet of 510.2 and 1050.6 for female and male strobili, respectively. The correlation between female and male strobilus production was positive in each of the four years studied and, with the exception of one year, statistically significant. The clonal status number $\left(N_{\mathrm{s}}\right)$, a measure of gene diversity, was calculated based on the observed clonal fertility variation and varied from $28.0(N=50)$ in the poorest flowering year (2002) to 46.7 in the best year (2005). On average (pooled), the relative status number was $95 \%$ of the census number $(N)$. Variation in female fertility was generally higher than that for male fertility, and this variation was reflected in the status numbers of female and male parents. The pooled $N_{s}$ estimated from all four years was higher than that for any single year, implying that gene diversity would increase when seeds collected from different years are pooled. Sexual asymmetry calculations showed that clonal contributions would be balanced between genders.
\end{abstract}

Key words: fertility variation, sibling coefficient, status number, effective number, sexual asymmetry, Chamaecyparis obtusa.

\section{Introduction}

Native to Japan, hinoki (Chamaecyparis obtusa Endl.) was introduced to Korea in the early $19^{\text {th }}$ century, where it has been traditionally planted on a wide variety of sites in southern parts of the country. Hinoki means "fire tree", referring to use of the wood to make fire by friction. The species is valued for appearance-grade lumber, and is also cultivated as an ornamental and shelterbelt species in warm-temperate climates. On the steep topography that is typical for forest land in Korea, hinoki is grown on upper slopes or hilly areas which are poor in fertility, whereas sugi (Cryptomeria japonica) is more commonly established on richer middle slopes or plains (YAMASHITA et al., 2004).

The Korean breeding program for hinoki started in 1960 with plus-tree selection of superior trees in local plantations. A total of 114 plus trees were selected phenotypically and used to establish the first clonal seed

1) Tree Breeding Division, Korea Forest Research Institute, 44-3 Omokcheon, Suwon, Kyonggi 441-350, Republic of Korea.

2) BioSylve Forest Science NZ Limited, 104 Delamare Road, Pukete, Hamilton, New Zealand.

*) To whom correspondence should be addressed: tel: +82 2901155 , fax: +82 292 4458. E-Mail: kangks@foa.go.kr orchards by means of rooted cuttings. The total area of hinoki seed orchard in the country now covers 48 ha, producing about $130 \mathrm{~kg}$ of seed per year.

Research on reproductive development in seed orchards has focused on the flowering behavior of trees and variation among clones (EL-KASSABY and AsKEW, 1991; HARJU, 1995). Ideally, clones in an orchard should flower during the same period (synchronization), exhibit similar periodicity of heavy flower production, yield similar numbers of viable seeds, have the same degree of self-incompatibility, and have a similar rate of growth and crown shape. Pollen contamination should also be minimized as much as possible (EL-KASSABY, 2000; KANG et al., 2001; GöMÖRY et al., 2003).

It is certain that this ideal behavior is never attained by orchards in the real world. On the other hand, research has demonstrated that seed orchards are robust and are highly suitable as sources of genetically improved seed for reforestation programs (YING et al., 1985; EdWARDS and El-KASSABY, 1996; NIKKANEN and RuOSALAINEN, 2000).

The main objectives of the present study were to determine the clonal variation in strobilus production (good or poor strobilus producers) in a clonal seed orchard of hinoki; to survey the female, male and overall clone fertility variation based on observed strobilus production; and, to monitor the gene diversity (determined by effective number) of seed crops in the orchard. Also, the effect of fertility variation on seed production is discussed.

\section{Materials and Methods \\ Seed orchard and data collection}

The seed orchard studied is located in Seogyupo, on Jeju Island (at $33^{\circ} 17^{\prime} \mathrm{N}, 126^{\circ} 38^{\prime} \mathrm{E}$ and altitude $550 \mathrm{~m}$ ), in the southernmost part of South Korea. The sixhectare seed orchard was established by rooted cuttings in 1982. Clones originated from a total of 52 plus trees, selected from plantations. The number of ramets established per clone varied from 1 to 154 (averaging 43.5 per clone). The design of the seed orchard was essentially random, and all cuttings were planted at $5 \mathrm{~m} \times 5 \mathrm{~m}$ spacing.

The numbers of female and male strobili were estimated for a total of 50 clones (96\% of the total clones). Five ramets per clone were chosen randomly, avoiding ramets growing at the edges of the seed orchard, and surveyed each year from 2002 to 2005 . The numbers of female and male strobili for each ramet sampled were estimated by multiplying the average number of strobili per branch by the total number of branches bearing strobili. 


\section{Fertility variation}

The female fertility variation $\left(\psi_{f}\right)$ and male fertility variation $\left(\psi_{m}\right)$ can be described by the coefficient of variation $(C V)$ in strobilus production, a measure suggested by KANG and LINDGREN (1999) as:

$$
\psi_{f}=C V_{f}^{2}+1 \text { and } \psi_{m}=C V_{m}^{2}+1
$$

where $C V_{f}$ and $C V_{m}$ are the coefficients of variation in female and male strobilus production among clones, respectively.

Clone fertility variation was estimated by the sibling coefficient $(\Psi)$ considering both female and male fertility variation (KANG and EL-KASSABY, 2002) as:

$$
\Psi=0.25\left(\psi_{f}+\psi_{m}+2\right)+0.5 r \sqrt{\left(\psi_{f}-1\right)\left(\psi_{m}-1\right)}
$$

where $r$ is the correlation coefficient between female and male strobilus production.

\section{Effective number and sexual asymmetry}

Effective number was calculated by the concepts of status number (LINDGREN and MULLIN, 1998) and effective parent number (KANG and LINDGREN, 1999). Status number calculations were based on the fertility variation at female, male and clone levels, respectively (KANG and LINDGREN, 1998) as:

$$
N_{s(f)}=\frac{N}{\psi_{f}}, N_{s(m)}=\frac{N}{\psi_{m}} \text { and } N_{s(c)}=\frac{N}{\Psi}
$$

where $N_{s(f)}, N_{s(m)}$ and $N_{s(c)}$ are the status effective numbers of female, male and clone, respectively. Yearly changes in $N_{s(f)}, N_{s(m)}$ and $N_{s(c)}$ were monitored. Relative status number was calculated as the ratio of status number $\left(N_{s}\right)$ over census number $(N)$.

The concept of sexual asymmetry $\left(A_{s}\right)$ was introduced by CHOI et al. (2004) to evaluate the degree of sexual asymmetry between female and male parents' contribution, and is estimated as follows;

$$
A_{s}=\frac{\left|N_{s(c)}-N_{a}\right|}{N_{a}} \text { where } N_{a}=\frac{N_{s(f)}+N_{s(m)}}{2} \text {. }
$$

\section{Results and Discussion}

\section{Strobilus production}

Average female and male strobilus production increased each year to a peak in 2005 (Table 1). The $C V$ values for both female and male strobili production were lowest in the best-flowering year (2005), while they were highest in the poorest flowering year (2002). On average (pooled), each ramet produced 510.2 and 1050.6 female and male strobili, respectively. The Pearson's correlation coefficients between female and male strobilus production were positive over all four years studied and, with the exception of 2003, statistically significant (Table 1).

Reproductive output of some clones was consistently high or low throughout the study period. This has been reported previously in several seed orchards (EL-KASSABY et al., 1989; GÖMÖRY et al., 2003), as well as in natural populations (BILA, 2001; XIE and KNOWLES, 1994). Clones whose reproductive output is consistently high or low might require special consideration during seed orchard thinning. In general, the main selection criterion in genetic thinning schemes is clonal genetic value (or breeding value) (EL-KASSABY and BARCLAY, 1992).

On the other hand, fertility is obviously a key aspect of seed orchard production. Fertility in many species is known to have generally moderate heritability (KANAZASHI and SAITO, 1989; GÖMÖRY et al., 2003). During seed orchard thinning, removing ramets of low fertility would thus be profitable for seed production. The data for strobilus production indicated that a few prolific clones could contribute a large proportion of the seed, particularly early in the orchard's development and for seedlots harvested during poor seed years (see also EL-KASSABY, 1989). In the present study, the count of strobilus production alone was applied to demonstrate the degree of variation in gametic contribution among clones. But, variation in reproductive output and phenology, as well as pollen contamination and spatial clone arrangement, all act individually or jointly on the accumulation of genetic relatedness and subsequent inbreeding in the progeny, and consequently affect the genetic properties of the seed (EL-KASSABY, 2003; GÖMÖRY et al., 2003; MoRIGUCHI et al., 2004).

\section{Fertility variation and effective number}

Fertility variation varied among years and between genders within years (Table 2). Female fertility variation $\left(\psi_{f}\right)$ was lower than male fertility variation $\left(\psi_{m}\right)$ in 2002, while $\psi_{f}$ was higher than $\psi_{m}$ in 2003, 2004 and 2005. However, overall clone fertility variation $(\Psi)$ within the seed orchard consistently decreased during the study period.

Table 1. - Average strobili per ramet, coefficient of variation $(C V)$ and correlation coefficient $(r)$ between female and male strobilus production over four years in a clonal seed orchard of Chamaecyparis obtusa.

\begin{tabular}{c|c|c|c|c|c|c|c|c|c|c}
\hline & \multicolumn{3}{|c|}{2002} & \multicolumn{2}{l|}{2003} & \multicolumn{2}{l|}{2004} & \multicolumn{2}{l}{2005} & \multicolumn{2}{l}{ Pooled } \\
\cline { 2 - 10 } & female & male & female & male & female & male & female & male & female & male \\
\hline Average & 56.6 & 111.9 & 100.2 & 794.2 & 363.9 & 1183.3 & 1338.8 & 1988.4 & 510.2 & 1050.6 \\
$C V$ & 0.991 & 1.029 & 0.856 & 0.502 & 0.659 & 0.410 & 0.284 & 0.205 & 0.242 & 0.160 \\
$r$ & $0.65^{* *}$ & 0.44 & & $0.72^{* *}$ & & $0.65^{* *}$ & & $0.62^{* *}$ \\
\hline
\end{tabular}

**: Statistically significant at the 0.01 level. 
Table 2. - Female $\left(\psi_{f}\right)$, male $\left(\psi_{m}\right)$ and clone fertility variation $(\Psi)$, and female $\left(N_{s(f)}\right)$, male $\left(N_{s(m)}\right)$ and clone effective number $\left(N_{s(c)}\right)$ in a clonal seed orchard of Chamaecyparis obtusa.

\begin{tabular}{|c|c|c|c|c|c|c|c|c|c|c|c|c|c|c|c|}
\hline & \multicolumn{3}{|l|}{2002} & \multicolumn{3}{|l|}{2003} & \multicolumn{3}{|l|}{2004} & \multicolumn{3}{|l|}{2005} & \multicolumn{3}{|l|}{ Pooled } \\
\hline & female & male & clone & female & male & clone & female & male & clone & female & male & clone & female & male & clone \\
\hline $\begin{array}{c}\psi_{f}, \psi_{m} \& \\
\Psi\end{array}$ & 1.98 & 2.06 & 1.84 & 1.73 & 1.25 & 1.34 & 1.43 & 1.17 & 1.25 & 1.08 & 1.04 & 1.05 & 1.06 & 1.03 & 1.03 \\
\hline $\begin{array}{c}N_{s(f)}, N_{s(m)} \\
\& N_{s(c)}\end{array}$ & 25.2 & 24.3 & 27.1 & 28.9 & 39.9 & 37.3 & 34.9 & 42.8 & 40.0 & 46.3 & 48.0 & 47.6 & 47.2 & 48.8 & 48.4 \\
\hline$N_{r}{ }^{*}$ & 0.50 & 0.49 & 0.54 & 0.58 & 0.80 & 0.75 & 0.70 & 0.86 & 0.80 & 0.93 & 0.96 & 0.95 & 0.94 & 0.98 & 0.97 \\
\hline
\end{tabular}

": relative effective number, $N_{r}=N_{s} / N$

It was reported by KANG et al. (2003) that a sibling coefficient of 2 would be typical in good or moderate flowering years in mature seed orchards, equal to a $C V$ of $100 \%$. In the present study, clone fertility variation for the pooled data (average) was close to one $(\Psi=1.04)$, implying that orchard clones were expected to make near-equal contributions to the seed crops. Actual contributions might differ due to phenology, clone arrangement, combining abilities or pollen contamination. The sibling coefficient $(\Psi)$ expresses the increase in the probability that sibs or relatives occur compared to the ideal situation where clones have equal fertility (KANG and LINDGREN, 1999). When $\Psi=1$, all genotypes have equal fertility.

Yearly changes in female, male and clone effective numbers mirrored the annual increase in seed production (Fig. 1), with all effective numbers increasing as the production of seed increased and the seed orchard matured. In general, fertility variation tends to be small and effective number large in good seed production years (REYNOLDS and EL-KASSABY, 1990; MATZIRIS, 1993; BurCZYK and ChAlUPKA, 1997; NIKKANEN and RuOSALAINEN, 2000). In 2005, the production of seed was highest and, as expected, the fertility variation was lowest (Fig. 1, Tables 1 and 2).

On average (pooled), the relative status number $\left(N_{r}\right)$ was $95 \%$ of the census number $(N)$. The pooled $N_{s}$ estimated from the study period was higher than that for any single year, implying that gene diversity would increase if seeds collected from different years are pooled. About $130 \mathrm{~kg}$ of hinoki seed from clonal seed orchards has been supplied annually in Korea, sufficient to establish approximately 1,200 ha per year. The genetic diversity of seed orchard crops will affect the level of diversity in seedling stages and subsequently of the plantations (i.e., accumulation of group coancestry).

Table 3. - Average of female and male status numbers $\left(N_{a}\right)$ and sexual asymmetry $\left(A_{\mathrm{s}}\right)$ in strobilus production between genders in a clonal seed orchard of Chamaecyparis obtusa.

\begin{tabular}{cccccc}
\hline & 2002 & 2003 & 2004 & 2005 & Pooled \\
\hline$N_{a}$ & 24.8 & 34.3 & 38.8 & 47.1 & 48.0 \\
$A_{s}$ & 0.10 & 0.08 & 0.03 & 0.01 & 0.01 \\
\hline
\end{tabular}

Sexual asymmetry $\left(A_{s}\right)$ varied from 0.01 in the most productive year to 0.10 in the poorest year, decreasing as the seed orchard matured (Table 3 ). By definition, $A_{s}$ ranges theoretically from zero to one (i.e., $0 \leq A_{s} \leq 1$ ). The relationship between $N_{a}$ and $N_{s(c)}$ can be generalized as $0 \leq\left(N_{s(c)}-N_{a}\right) \leq N_{a}$. An As value of zero indicates perfect sexual symmetry; there is maximum sexual asymmetry if $A_{s}=1$. In general, $N_{a}$ is equal to or smaller than $N_{s(c)}$, but it might be larger when there is an extreme difference between $N_{s(f)}$ and $N_{s(m)}$ (CHOI et al., 2004).

MÜLLER-STARK (1982) reported variation between female and male contributions of each clone, indicating differential ovule and pollen production in a clonal seed orchard of $P$. sylvestris. Such deviation would affect, in terms of sexually asymmetrical fertility-selection, the resulting genetic structure of the seed crop, with a surplus of heterozygous offspring.

\section{Acknowledgements}

Portions of this study were completed when T. J. MuLLIN visited the Korea Forest Research Institute during the fall of 2005. The authors thank to Mr. KANG B. S. for his help during collecting data. This study was supported by the Korea Forest Research Institute.

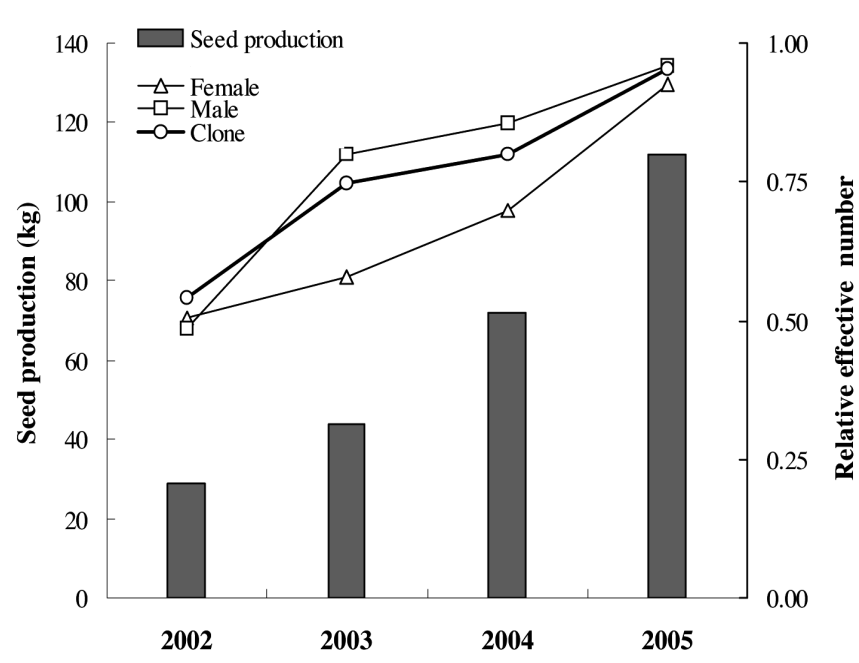

Figure 1. - Relation between seed production and female, male and clone effective numbers in a clonal seed orchard of Chamaecyparis obtusa. 


\section{References}

BILA, A. (2000): Fertility variation and its effects on gene diversity in forest tree populations. Ph.D Thesis. Swedish University of Agricultural Science, Umeå, Sweden. Acta Universitatis Agriculturae Sueciae, Silvestria 166. 31pp.

BuRCZYK, J. and W. CHALUPKA (1997): Flowering and cone production variability and its effect on parental balance in a Scots pine clonal seed orchard. Ann. Sci. For. 54: 129-144.

CHOI, W. Y., K. S. KANG, S. U. HAN and S. D. HuR (2004): Estimation of heritabilities and clonal contribution based on the flowering assessment in two clone banks of Pinus koraiensis S. et Z. Proc. of IUFRO 2.02.15 (Breeding and genetic resources of five-needle pines). July 24-27, 2001, Medford, Oregon, USA. USDA Forest Service Proceeding RMRS-P-32. 2004. p.172-177.

Cockerham, C. C. (1967): Group inbreeding and coancestry. Genetics 56: 89-104.

EL-KASSABY, Y. A. (2000): Effect of forest tree domestication on gene pools. In: Forest Conservation Genetics: Principles and Practice. Commonwealth Scientific and Industrial Research Organisation (CSIRO) (Young, A., D. Boshier and T. Boyle, eds.). CSIRO PublishingCABI Publishing, Canberra, Australia. Chapter 13 197-213.

EL-Kassaby, Y. A. (2003): Clonal-row vs. random seed orchard design: mating pattern and seed yield of western hemlock. For. Genet. 10: 121-127.

EL-Kassaby, Y. A. and G. R. Askew (1991): The relation between reproductive phenology and reproductive output in determining the potential gametic pool profile in a Douglas-fir seed orchard. For. Sci. 37: 827-835.

El-Kassaby, Y. A. and H. J. BARCLAY (1992): Cost of reproduction in Douglas-fir. Can. J. Bot. 70: 1429-1432.

El-Kassaby, Y. A., A. M. K. FAshleR and M. CRown (1989): Variation in fruitfulness in a Douglas-fir seed orchard and its effect on crop-management decisions. Silvae Genet. 38: 113-121.

GÖmÖRY, D., R. BRUChANIK and R. LONGAUER (2003): Fertility variation and flowering asynchrony on Pinus sylvestris: consequences for the genetic structure of progeny in seed orchards. For. Ecol Manage. 174: $117-126$

KANAZASHI, T. and M. SAITO (1989): Estimation of heritabilities of cone and seed traits in Pinus densiflora Sieb. et Zucc. by parent-offspring regression. Bulletin of the Forestry and Forest Products Research Institute, Ibaraki (No. 355): 117-131.

KANG, K. S. and Y. A. El-Kassaby (2002): Considerations of correlated fertility between genders on genetic diversity: Pinus densiflora seed orchard as a model. Theor. Appl. Genet. 105: 1183-1189.
KANG, K. S. and D. LindGREN (1999): Fertility variation among clones of Korean pine (Pinus koraiensis) and its implications on seed orchard management. For. Genet. 6: 191-200.

Kang, K. S., A. D. Bila, A. M. HarJu and D. Lindgren (2003): Fertility variation in forest tree populations. Forestry 76: 329-344.

LindGren, D. and T. J. Mullin (1998): Relatedness and status number in seed orchard crops. Can. J. For. Res. 28: $276-283$.

MATZIRIS, D. I. (1993): Variation in cone production in a clonal seed orchard of black pine. Silvae Genet. 42: 136-141.

Moriguchi, Y., H. TAIRA, N. TANI and Y. Tsumura (2004): Variation of paternal contribution in a seed orchard of Cryptomeria japonica determined using microsatellite markers. Can. J. For. Res. 34: 1683-1690.

MÜLlER-STARK, G. (1982): Sexually asymmetric fertility selection and partly self-fertilization. 2 . Clonal gametic contributions to offspring of Scots pine seed orchard. Silva Fenn. 16: 99-106.

Namba, H., K. Saitou, N. Sahashi, M. Yamamoto, T. Yoshida, H. Ogasawara, M. Fujimoto and N. Asada (2001): Relationship between pollen counts of Cryptomeria japonica and Cupressaceae and the severity of allergic symptoms. Allergology International 50: 133-142.

NiKKANEN, T. (2001): Reproductive phenology in a Norway spruce seed orchard. Silva Fenn. 35: 39-53.

NIKKANEN, T. and S. RUOSALAINEN (2000): Variation in flowering abundance and its impact on the genetic diversity of grafts of Pinus sylvestris. For. Ecol. Manage. 19: $35-40$.

Reynolds, S. and Y. A. El-Kassaby (1990): Parental balance in Douglas-fir seed orchards-cone crop vs. seed crop. Silvae Genet. 39: 40-42.

TAIRA, H., Y. Tsumura, Y. TOMARU and K. OHBA (1997): Regeneration system and genetic diversity of Cryptomeria japonica growing at different altitudes. Can. J. For. Res. 27: 447-452.

XIE, C. Y. and P. Knowles (1994): Mating system and effective pollen immigration in a Norway spruce (Picea abies (L.) Karst) plantation. Silvae Genet. 43: 48-52.

Yamashita, T., N. KasuYa, S. Nishimura and H. TAKedA (2004): Comparison of two coniferous plantations in central Japan with respect to forest productivity, growth phenology and soil nitrogen dynamics. For. Ecol. Manage. 200: 215-226.

Ying, C. C., J. C. Murphy and S. Andersen (1985): Cone production and seed yield of lodgepole pine grafts. For. Chron. 61: 223-228. 